\title{
Mental Models and the Europe 2020 Strategy: Neo-schumpetarian Ideas in Innovation and Education
}

Conrad King

University of British Columbia

\begin{abstract}
This article asks how ideas have mattered for the establishment of policy goals for the Europe 2020 Strategy. I argue that despite the specification of new environmental and social targets, the overall policy goals of Europe 2020 remain consistent with the 2000 Lisbon Agenda because the European Council and the European Commission have had resilient causal beliefs about the challenges of globalization, as well as the appropriate responses to these challenges. Using Alan Jacobs's theory of mental models and attention heuristics, this article describes the connection between neo-schumpetarian ideas and the policy outcomes of Europe 2020, particularly in the domains of innovation and education policy. Establishing this connection is an essential first step to explain precisely how ideas can determine and maintain the policy preferences of particular EU actors, a direction for future research.
\end{abstract}

Keywords: Europe 2020; education policy; innovation policy; ideas 


\section{Introduction}

On March 3, 2010, European Commission President Jose Manuel Barroso announced the launch of the Europe 2020 Strategy, a ten year economic plan for the European Union to balance economic growth, social inclusion, and environmental protection. Although the Strategy has received criticism for lacking public consultation and for being too ambitious to implement effectively, its central goal of 'smart, sustainable, inclusive growth' has received considerable support as an appropriate new direction for the EU. Social and environmental civil society groups have perceived Europe 2020 as a kind of 'promissory note' for an increasingly reflexive view of modernity (Beck, 2009; Commission, 2010a; Platform of European Social NGOs, 2009). Yet the powerful EU actors who set policy goals have emphasized endogenous economic growth through innovation, research, and education. So ideas clearly seem to matter for Europe 2020, but which ideas? And how do they matter? This paper addresses the former question in order to form hypotheses about the latter, which will be the subject of future research.

Europe 2020 offers a case study for understanding how ideas influence political elites when they set high-level policy priorities in conditions of 'insulated' decision-making (where effectiveness is more important than accountability). What are the ideas that led to the Europe 2020 Strategy and where did they come from? Why is a theory of ideational causation appropriate for understanding Europe 2020? Is there a particular ideational theory that offers explanatory leverage for the conditions of high-level policy-making within the executive institutions of the European Union? I argue that despite the specification of new environmental and social targets, the overall goals of Europe 2020 remain consistent with the 2000 Lisbon Agenda because the mental models of EU political actors have not significantly changed. These actors' causal beliefs about the challenges of globalization, as well as the appropriate responses to these challenges (manifest in policy preferences), have remained consistent over time, and are now seen in the policy outcomes of Europe 2020. The 2000 Lisbon Council constructed a neoschumpetarian mental model of reality, influenced by an epistemic community of European economists. The Commission then set the EU on an endogenous growth trajectory emphasizing innovation and human capital, a model that now pervades Europe 2020, even if some of the individual actors have changed. Alan Jacobs's theory of mental models and attention heuristics can explain the causal link between ideas and policy preferences, whereas this paper describes the more general connection between ideas and policy outputs, particularly in the domains of innovation and education policy. Establishing this connection is an essential first step to explain precisely how ideas can determine and maintain the policy preferences of particular EU actors (like European Commissioners) at the level of individual cognition. Thus, this descriptive first step will link ideas to outcomes in a general way, as a preparation for subsequent research that will process-trace the empirics of how ideas determine policy preferences for political elites under conditions of insulated decision-making.

\section{The Europe 2020 Strategy: Background and Context}

The Europe 2020 Strategy is the economic and employment plan for the European Union for the next decade. The Strategy lays out goals and targets, as well as the means to achieve them, in an overarching mission statement for the future of the European Union. The blueprint for this kind of strategy statement was the Lisbon Agenda, borne out of a meeting of the European Council in 
Lisbon in 2000. At the time, European integration had been greatly consolidated through the Treaties of Maastricht and Amsterdam especially vis-à-vis economic and monetary union, yet the EU remained under tremendous pressure to set goals (and justify itself) amidst a prolonged recession in the late 1990s. Following the 2000 Council meeting in Lisbon, the Commission could announce an EU economic strategy for the coming decade. With the Lisbon Agenda expiring in 2010, and in the context of a highly uncertain global financial environment in the late 2000s, the EU wanted to establish new goals and governance for the period 2010 until 2020. The Europe 2020 Strategy is the expression of that vision.

Like the Lisbon Agenda, Europe 2020 is fundamentally a strategy for economic growth. While it is constructed on three mutually-reinforcing 'pillars'-economic, social, and environmental-its primary raison d'être is to ensure the economic viability of the EU. The Council and Commission envision economic growth that is driven by knowledge and innovation, that decouples growth from the use of carbon-emitting non-renewable resources, and that builds a cohesive society where people are empowered to manage change and actively participate in the new knowledge economies - the EU as "a smart, sustainable and inclusive economy" (Commission, 2010b). The strategy has five 'headline' targets: to raise the employment rate from the current 69 percent to at least 75 percent; to have 3 percent of member states' GDP invested in research and development $(R \& D)$; to reduce the share of early school leavers from the current 15 percent to 10 percent plus increase the share of the population aged 30-34 having completed tertiary education from 31 percent to at least 40 percent; a 25 percent reduction in those living below national poverty lines; and to implement the 'Europe 20/20/20' strategy aimed at significantly reducing greenhouse gas emissions. ${ }^{1}$ These targets seem to signal a departure from the previous Lisbon Agenda, in that social and environmental targets are better incorporated. Yet a social agenda (and eventually a rather nominal environmental agenda) were part of Lisbon as well, only to be subordinated to employment and growth when Member State economies continued to struggle in the early 2000s. Like its predecessor, Europe 2020 has positioned economic and employment policy as central, although conceivably the social and environmental goals can be supportive of and integrated into those objectives.

In comparison with Lisbon, the Europe 2020 Strategy proposes new means for achieving these objectives. The governance structure of the Strategy is based on an architecture of two 'pillars': a 'thematic approach' and 'country reporting'. The thematic approach combines the five targets mentioned above with more specific priorities and initiatives, which require action at both the EU and Member State level. This is meant to reflect an increased EU dimension in the interdependent Member State economies. The country reporting pillar is a feedback mechanism between Member States and the EU, which would allow Member States to develop countryspecific growth strategies with guidance and coordination from the Commission (who would also keep the larger pan-European vision in mind). This pillar is adapted from the primary governance mechanism of the Lisbon Agenda: the Open Method of Coordination (OMC). The OMC is an intergovernmental governance tool which relies on voluntary communication between governments along with limited Commission guidance (through mechanisms such as stocktaking, benchmarking, peer review, and naming-and-shaming) in order to affect a 'soft' coordination of national policy outputs rather than a 'hard' regulatory policy framework as legislated through the EU. The country reporting pillar stiffens up elements of the OMC by

1. To reduce greenhouse gas emissions by at least 20 percent compared to 1990 levels (or by 30 percent if global conditions are right), to increase to 20 percent the share of renewable energy in overall energy consumption, and to increase energy efficiency by 20 percent.

(c) 2012 The Author(s)

www.carleton.ca/rera 
making communication mandatory (and not just between states) and by giving the Commission a stronger coordinating role in terms of issuing policy 'recommendations' as well as warnings if Member States do not comply (although the penalty for non-compliance has yet to be determined). The basic Europe 2020 architecture has then been incorporated into a larger process - the European Semester-which coordinates general economic policy with the fiscal surveillance mandate of the Stability and Growth Pact (SGP). All reporting and evaluation for both Europe 2020 targets and SGP responsibilities are to be done simultaneously to best coordinate the aims and means of each, while keeping their instruments and procedures legally separate "to maintain the integrity of the SGP" (Commission, 2010b, pg. 4). ${ }^{2}$ The intent of the new governance architecture is to build on the strength of already existing coordination instruments (like the OMC) and incorporate new decision-making procedures from the 2009 Treaty of Lisbon in order to instil greater ownership of the Europe 2020 Strategy for all actors involved (Ibid.).

Ostensibly, much of the Strategy entails ideas about the aims of an EU economy, and ideas about how the EU should go about achieving those aims. Within the thematic approach pillar, there is an overlap between aims and means by virtue of seven 'flagship initiatives.' Although all seven action plans are interrelated, this paper will focus on the first two: 'Innovation Union' and 'Youth on the move.' ${ }^{3}$ The Innovation Union aims "to improve framework conditions and access to finance for research and innovation so as to strengthen the innovation chain and boost levels of investment throughout the Union” (Commission, 2010c). Youth on the move aims to "enhance the performance of education systems and to reinforce the international attractiveness of Europe's higher education" (Ibid.). Both are initiatives with core goals categorized within the economic pillar, as they are classified as growth that is 'smart' more so than sustainable or inclusive. These initiatives represent likely 'plausability probes' (Eckstein, 1992, pgs. 147-52) for any theory which posits that actors' preferences are caused by ideational factors in which economic ideas are the structuring heuristic. This is because actors' ideas about economics are likely to structure economic policy preferences before they apply to social and environmental policy preferences. In short, if an ideational theory can tell us nothing about the conditions when economic ideas structure economic policy preferences and outcomes, then this theory is even less likely to inform us of the conditions when economic ideas structure other policy domains. Therefore, innovation and higher education are two areas where we are likely to see economic ideas being translated into economic policies.

\section{Ideational Theory: Mental Models and the Attention Heuristic}

Perhaps it is not surprising that ideas are salient for Europe 2020, given the degree to which European political elites can translate their preferences into high-level policy priorities. However, assuming that ideas matter is not the same as assessing the ways that they matter. A

2. Arguably, this privileges the SGP. The current priorities seem to be fiscal responsibility and austerity rather than economic growth.

3 The other five are: 'A Digital Agenda for Europe'; 'Resource efficient Europe'; 'An industrial policy for the globalisation era’; ‘An agenda for new skills and jobs’; and ‘European platform against poverty’ (European Commission, 2010c) 
succinct analysis of rationalist explanations will reveal that ideas do indeed have causal effect on Europe 2020, due to the structural and cultural characteristics of the executive institutions of the EU which seem to privilege visionary ideas over material interests or conditions. Executive functions for the EU are divided between the Council and the Commission, with neither body directly accountable to an electorate when they establish European policy priorities. Although the intergovernmental Council is comprised of elected heads of government, they function as heads of state in Council, such that they are not ex ante accountable to domestic constituents or national parliaments for high-level strategy or steering of European integration. Specific policy is not discussed in this setting, obviating attempts to 'upload' policy from the national to the European level, as occurs in the various Councils of Ministers. Moreover, the critical actor for European policy initiation and implementation is the agenda-setting Commission, an appointed body, and one that reaches internal consensus in private. Therefore, strategic interests are muted because there are few incentives for political elites to seek votes, office, or specific policies, and because decision-making is occurring out of the public eye. Functionalist explanations also assume that actors will respond rationally, although to changes in material conditions. If functional explanations were especially salient, one would expect that the parallels between the Lisbon Agenda and Europe 2020 were a reflection of similar conditions in the late 1990s and the late 2000s. However, much changed over that decade, in terms of internal power dynamics (the Lisbon Treaty, EU enlargements in 2004 and 2007), and external economic shocks (the 2008 financial crisis). Thus, considerable changes in material conditions spurred only modest alterations in the economic plan, primarily vis-à-vis adjustments in governance mechanisms. This is not to suggest that political elites are irrational, or that material interests and conditions do not factor into policy outcomes; ideas are not mono-causal inputs, and policy outcomes are often determined by various factors operating in conjunction. However, rationalist theories about policy-making take preferences as given, whereas ideational theories are concerned with the formation of preferences. There are circumstances when ideas strongly determine policy preferences, and with the right conditions, those preferences can strongly determine policy outputs. Europe 2020 offers a set of conditions whereby ideational preferences seem to have particular salience - a small political elite that respond to ideas for appropriate policy responses because they have weak accountability, little deliberative transparency, and are concerned with 'output legitimacy', i.e., they are governing for the general welfare, rather than by general consent (Scharpf, 1999). If preferences are constructed from mental models, then an ideational theory would help us to understand not only preference formation, but also, under conditions of insulated decision-making, how ideas can become policy outputs.

Ideas have long been considered a source for public policy, yet ideational theories seldom specify the mechanisms by which ideas can cause particular outcomes. This paper is concerned with ideas as micro-level causal inputs —as cognitive structures in the minds of political elites - which guide both their responses to policy choices as well as the ways that they construct choice scenarios. Conceiving of ideas in this way goes beyond IR approaches that posit ideas as general worldviews, values, or causal beliefs, or as discourses diffused from international organizations to national policy-makers (Goldstein \& Keohane, 1993; Jakobi, 2009). It also goes beyond public policy theories which restrict ideas to the agenda-setting and policy-formulation stages of the policy cycle; or theories that limit ideas to explaining how governments solve problems or frame issues (Bleich, 2002; Heclo, 1974; Howlett \& Ramesh, 1995; Kingdon, 1984). Presenting ideas as broad and somewhat nebulous constructs with little measurable input for policy-making, or else as narrow instrumental tools used at particular stages of policy 
construction, is saying that ideas matter, but only through loose correlation with policy outcomes or else as a kind of 'noise' - mopping up variance not explicable (or measurable) via interests and institutions. What is needed is an ideational theory that causally links ideas to preferences, especially if those preferences are explicit in policy outputs. This paper is a plausibility probe that offers an initial assessment of the latter, but calls on theoretical underpinnings to establish the mechanisms of the former.

Alan Jacobs' (2009) theory of mental models can both describe the changes in Europe 2020 policy (inasmuch as they are a reflection of actors' preferences) as well as explain how those preferences come about. Jacobs argues that actors have pre-existing mental models which narrow the range of possible consequences and preferences before problem analysis even occurs. These mental representations have descriptive and causal content-concepts, their attributes, and the relationships amongst attributes — which steer actors to ignore or attend to particular sets of data or causal explanations. The causal mechanism operates on the level of individual cognition; an 'attention heuristic' that goes beyond just issue selection to skew attention towards certain possibilities and ordering the actor's preferences therein. ${ }^{4}$ Jacobs' theory has particular leverage because it can explain the relationship between ideas and preferences, and describe the relationship between preferences and policy outcomes. Because it is a relatively new theory, Europe 2020 is a good empirical case because of its probative value (i.e., hypothesis formation and theory-building). Furthermore, 'ideas as attention' can explain conditions of change or stability for policy outcomes. If outcomes remain stable, the attention heuristic acts as a confirmation bias towards evidence that is consistent with a pre-existing schema. If outcomes change, it is because the attention heuristic caused actors to widen their search for information (within a finite range of possibilities) to account for an accumulation of disconfirming evidence which diverges from expectations and weakens the existing mental model. Therefore, this theory has particular utility for Europe 2020 because it accounts for incremental policy change during a period of relative policy stability. It allows one to examine the policy platform and connect it with actors' ideas, even if the final outcomes remain years away.

My method for this paper is to describe the connection between the ideas of the Lisbon Agenda, and the preliminary policy outcomes of Europe 2020. If this relationship can be established, there is good reason to analyze - in future research - the causal mechanisms of how attention heuristics determine policy preferences. If ideas are indeed salient for policy outcomes, I hypothesize that there should be a clear and sequential pathway from ideational origins to policy outcomes that leaves an observable footprint. We would expect to see early interaction between certain economic thinkers and powerful political elites, subsequent adoption of their ideas, and over time, those same ideas would become anchored in the institutional norms and beliefs of a small, socializing organization such as the Commission. Future research would entail examining public statements, proto-policy documents, private correspondences, and deliberations between political elites and ideas-makers, as well as their temporal sequence. There could well be non-ideational causal variables that are collinear with ideas, but process-tracing should parse out such co-variation. If ideas are salient in a particular way for the conditions present in the development of Europe 2020, I hypothesize that they matter most for preference formation at the micro-level. Had Europe 2020 seen significant policy change, it might have been theorized in a number of other ways: as a response to material interests or conditions; as the

4. This is more than just a theory of ideas. It argues that ideas influence what institutions and material interests will be possible, irrespective of the seemingly complete range of probabilities that a boundedly-rational actor might consider. 
result of an accumulation of policy anomalies leading to paradigmatic 'third-order' change (Hall, 1993); or as the result of a critical juncture which caused actors to no longer understand how to structure their interests in light of systemic risk and thus seek new ideas to reduce this 'Knightean' uncertainty (Blyth, 2002). Instead, the stability of policy between the Lisbon Agenda and Europe 2020 is a hypothesis consistent with a theory that posits that actors' ideas serve as attention heuristics. Finally, if particular ideas were salient for Europe 2020, then I hypothesize that the content of those ideas would be visible in policy outputs. This final hypothesis is what this paper addresses; it is a case study on outcome-continuity over time, linking the ideas that preceded the Lisbon Agenda to the policy outputs of Europe 2020. Such a case study functions as a plausibility probe to develop the other hypotheses through future research.

\section{Attention to Goals: ‘Smart Growth’ and the Europe 2020 Strategy}

The European Council constructed the Europe 2020 Strategy on three ideational pillars: the economy, a social dimension, and the environment. However, the five main targets and seven flagship initiatives which specify the goals of the Strategy make it clear that the primary aim of Europe 2020 is to rejuvenate Europe's flagging economy and set it back on a growth trajectory. The other pillars are undoubtedly important, but they are positive externalities and cultivated spillover effects of centrally-guided economic growth. Social inclusion is a presumed subsidiary effect from increased labour market integration, and environmental protection/damagemitigation is facilitated by the creation of a sustainable resource-efficient economy. ${ }^{5}$ The ideas behind these goals are causal beliefs about how to manage economies, not societies or ecological systems. As such, the 'smart growth' pillar is the driver of the entire Strategy, and the aim is to build up capacity for endogenous supply and demand of the 'products' of the new knowledge economies: skilled human capital plugged into technologically-innovative industries. If the Commission can succeed in implementing this primary goal, then the other pillars will also be served. Because implementation —and not ideas — was deemed the shortcoming of the Lisbon Agenda, the Commission has issued integrated guidelines to Member States to achieve the headline targets. These integrated guidelines make clear that Member States are obliged to achieve Europe 2020 targets because of their commitment to the 2009 Lisbon Treaty, yet it also reflects a perception at the European level of what innovation and education are really for.

The innovation target is under the jurisdiction of Article 121 TFEU (economic policy) and the educational target - even though education has never been an EU jurisdiction - is subsumed under Article 148 TFEU (EU employment policy) (European Commission, 2010c; TFEU, 2008). It appears that the mental model for Europe 2020 has endogenous economic growth as the 'engine' of the European Union - education and innovation are inputs, and social inclusion or environmental protection are desirable outcomes.

The Innovation Union is the first flagship initiative, and it aims to boost R\&D funding and re-focus innovation to tackle challenges facing European societies, such as climate change,

5. An example of how the EU can intervene and still be market-making is the EU Emissions Trading Scheme (ETS). Although the ETS clearly has environmental benefits, it is also premised on the Porter hypothesis: stringent environmental regulations will spur firms to innovate, and the newly discovered technologies should offset the initial abatement and R\&D costs vis-à-vis efficiency gains and first mover advantages (in the global market for green technology). The effect that the ETS has on European innovation or creating a global market for that innovation remains to be seen (Oberndörfer, 2011; Palmer, Oates, \& Portney, 1995; Porter \& van der Linde, 1995)

(C) 2012 The Author(s)

www.carleton.ca/rera 
energy and resource efficiency, health, and demographic change. It is a response to causal beliefs about innovation and R\&D as drivers of economic-growth, and a result of EU actors' attention being focused on data which shows Europe is falling behind in these domains. ${ }^{6}$ The EU headline target is to have 3 percent of EU GDP invested in R\&D by 2020. ${ }^{7}$ The Commission has a number of strategies to accomplish this central goal: to create a 'single market' for the mobility of knowledge by 2014 (the European Research Area); to protect business innovation (especially SMEs, via a single EU Patent and improved Intellectual Property Protection); to foster innovation at all levels of government (through public procurement and European Innovation Partnerships); to subsidize innovation in order to better commercialize new technology (through the European Investment Bank and by strengthening EU funding mechanisms ${ }^{8}$ ); and to strengthen the 'knowledge triangle' with partnerships between industry and institutions for education and research (through the European Institute of Technology and the Young Innovative Companies programme). ${ }^{9}$ The Commission must also coordinate Member States to ensure a sufficient supply of science, maths and engineering graduates with entrepreneurial skills, prioritize knowledge expenditures through public spending and tax incentives for private $R \& D$ investments, and reform national (and regional) R\&D and innovation systems by way of 'smart specialization' (Commission, 2010b, pgs 10-11). ${ }^{10}$ These strategies and targets reflect an attention heuristic limited to economic ideas for Europeanizing innovation and modernizing research and development systems. Key concepts are innovation, entrepreneurship, competition, endogenous economic growth, and free markets. While this flagship initiative is not exclusively demand-driven (supply of innovative technology is critical to the EU's external/international dimension), it does represent the demand-side of a European knowledge economy within the 'single market' for labour and capital. Thus, the Innovation Union is the result of powerful EU actors having a pre-existing mental model of the world as a competitive market that rewards innovation.

'Youth on the move' is the second flagship initiative, and it aims to increase the quality of human capital in Europe by enhancing the performance and international attractiveness of

6. "R\&D spending in Europe is below 2 percent, compared to 2.6 percent in the US and 3.4 percent in Japan, mainly as a result of lower levels of private investment. It is not only the absolute amounts spent on R\&D that count - Europe needs to focus on the impact and composition of research spending and to improve the conditions for private sector R\&D in the EU” (European Commission, 2010b, pg 10).

7. Like the Lisbon Agenda, indicators for Europe 2020 remain quantitative and focused on GDP. For this particular target, the Commission intends to construct more nuanced and qualitative indicators. They would like to see a significant portion of the 3 percent GDP being contributed by the private sector. Furthermore, they are still developing an indicator to track innovation intensity, i.e., it is not merely amount of R\&D investment that is important, but also the quality and destination of that investment (Commission, 2010c).

8. A key delivery mechanism is a greater use of structural funds under cohesion policy. However, this might conflict with the Common Agricultural Policy (CAP), which still consumes over one third of the EU budget. The European Economic and Social Committee has asked that all EU budget instruments be directed to Europe 2020 goals, even if that means a modification of CAP objectives (European Economic and Social Committee, 2011, p. 4)

9. The 'knowledge triangle' refers to a concerted effort to link research, education and innovation. It is the cornerstone of 'smart growth' and the justification for the European Institute of Technology, a project first presented by the Commission in 2005. The EIT is modelled after the Massachusetts Institute of Technology, but it also reflects a wider move to emulate the American system of higher education where research activities are concentrated into less than 10 percent of HEIs (Commission, 2006)

10. Smart specialization refers to the clustering of research and innovation to achieve a critical mass for a national or regional comparative advantage in particular technologies. Ex-ante conditional funding for these 'RIS3 strategies' is available from the Commission's $7^{\text {th }}$ Framework Programme for Research, Technological Development and Demonstration (RTD) 2007-2013 (European Commission, 2005). 
European higher education institutions, promoting student and instructor mobility, and facilitating youth employment. It is a response to causal beliefs about skilled human capital as an essential component to knowledge economies, and the result of EU actors' attention being focused on data that shows the comparative deficiency of European education and training systems. ${ }^{11}$ To overcome these challenges and accomplish its goals, the Commission needs to: enhance mobility of students and instructors (via EU programmes like Erasmus but also by supporting the European Higher Education Area); modernize the curricula, governance and financing of higher education systems (already underway via the Bologna Process); promote entrepreneurialism (through competitive funding mechanisms); promote the recognition of nonformal and informal learning (Life Long Learning); and facilitate youth employment (the Youth employment framework and the 'EURES job’ scheme). The Commission must also motivate the Member States to invest in education and training systems at all levels, improve educational outcomes, and enhance the openness and relevance of education systems (via national qualification frameworks that emphasize learning outcomes geared towards labour market needs) (Commission, 2010b, pg. 11). The headline target is to reduce the primary/secondary drop-out rate to just 10 percent, while increasing the share of the population aged 30-34 who have completed tertiary or equivalent education to at least 40 percent by 2020 . This reflects an attention heuristic relatively constrained by economic ideas about education and training as a functional necessity for participation in the labour market of the new knowledge economies i.e., education as an investment in human capital (Commission, 2010c; ECOFIN, 2010). Key concepts are knowledge economies, the knowledge triangle, human capital, 'flexicurity', global competitiveness, and mobility across the single market. ${ }^{12}$ This flagship initiative emphasizes the supply-side of knowledge economies by way of improving human capital formation. Thus, 'Youth on the move' is the result of powerful EU actors having a pre-existing mental model of a world where education and training is an investment in human capital to affect better labour market integration.

\section{Neo-Schumpetarianism from Lisbon to Europe 2020}

The economic idea behind the Europe 2020 strategy is 'neo-schumpetarianism', a mental representation of reality that emphasizes innovation, entrepreneurship, competition, and free markets. ${ }^{13}$ In his book Capitalism, Socialism and Democracy, Joseph Schumpeter envisioned innovation and entrepreneurship as the drivers of constant economic change vis-à-vis a process of 'creative destruction.' Competition in free markets could facilitate the creative destruction of not only old products and processes, but also the very institutions that buttress obsolete social

11. "Less than one person in three aged 25-34 has a university degree compared to 40 percent in the US and over 50 percent in Japan. According to the Shanghai index, only two European universities are in the world's top 20”

(European Commission, 2010b, pg.11).

12. a 'fifth' freedom in the single market: free movement of knowledge

13. These are not all fundamentally capitalist concepts; innovation and technological change has been a driving force in many human societies. Pre-modern China was a great innovator (paper, printing, gunpowder, the compass) and although long-since overtaken, it has recently adapted its economy to be quite adept at 'process' innovation in manufacturing. However, in the modern era, innovation seems to have become a core capitalist heuristic: "one way of defining it would be as fresh thinking that creates value people will pay for" (emphasis added) ("From brawn to brain,” 2012, pg. 23). 
relationships (Schumpeter, 1994 [1942], pg. 139). ${ }^{14}$ Neo-schumpetarians emulate the core of this mental model of competition-induced endogenous growth, but believe that a more involved state (or a state-like governance network) can guide and facilitate competition and markets. There is an expectation of 'value added' spillovers and positive externalities in all sectors of the economy and even all sectors of society i.e., all policy domains become functions of economic decisionmaking. Exogenous factors - like international comparative advantage or external shocks-are not outside the heuristic logic of this mental model. Instead, political actors try to shelter comparative advantages while allowing less robust or less competitive parts of the economy to fail. Furthermore, actors can facilitate long-term development and modernization of the economy through (seed) investments in human capital, innovation, and knowledge. ${ }^{15}$ Neo-schumpetarian thinkers advocate a competitive innovative economy with a prominent market-making role for a governing body, the core idea behind the Europe 2020 Strategy.

Where did this mental model come from? Europe 2020 policy outcomes indicate that EU actors' policy preferences have been heuristically-focussed on the macro-economic theories of a particular group of European economists, amongst them Maria João Rodrigues, Christopher Freeman, Luc Soete, Bengt-Åke Lundvall, and Manuel Castells (Castells \& Cardoso, 2005; Rodrigues \& et. al., 2009; Zuleeg \& Rodrigues, 2011). This same epistemic community was instrumental in the late 1990s for shifting attention away from attempts to manage globalization effects vis-à-vis a stability-oriented, multi-lateral, regulatory framework for global financial markets, towards attempts to manage globalization effects vis-à-vis a growth-oriented Lisbon Strategy (Abdelal \& Meunier, 2010; Haas, 1993). True to Jacobs's theory of resilient mental models, Lisbon policies do not suggest a complete departure from the economic ideas that preceded it - the single market, the four freedoms, a common currency, and a strong economic and trade governance role for the EU - these remained central to policy-makers attention heuristic. However, there was some shift away from a stability-oriented plan because the special European Council in Lisbon perceived the need for "a radical transformation of the European economy" (Council, 2000). The policy outcomes of the Lisbon strategy demonstrate a somewhat radical (but certainly not total) transformation of ideas about the drivers of globalization and how they might appropriately respond; by transforming the EU into "the most competitive and dynamic knowledge-based economy in the world, capable of sustainable economic growth with more and better jobs, and greater social cohesion" (Ibid.). Economic competitiveness and social cohesion were the main pillars, and the strategy was to modernize innovation and education systems. Even if Lisbon was crafted as a political compromise between neo-liberals and leftist advocates of a 'social Europe', the fact remains that such an alliance was based on a coherent idea that might ease implementation, rather than on strategic interests that would produce sub-

14. Schumpeter's ideas were explicitly derived from Marxist economic theory, and so he perceived reality through a historical materialist lens. His contemporary and co-national, Karl Polanyi, offered a rival empirical explanation and normative counterpoint to Schumpeterian logic and its implications. Polanyi argued that a strong state was required to both facilitate and mitigate capitalism's destructive elements, but also that a self-regulating market society is unsustainable because civic society would (and should) spontaneously move to protect itself (Evans, 2008; Polanyi, 2001 [1944]). Arguably, Polanyian economic ideas had significant influence on the mental model of powerful political actors in the early years European Community (from perhaps the 1950 Treaty of Rome until the 1987 Single European Act).

15. The degree to which an innovative economy should be sheltered or facilitated delineates different schools of thought in neo-schumpetarian macro-economic theory. Aghion and Howitt (1992) caution against too much (or too little) market-shaping investment in innovation, whereas Freeman and Louça (2001) suggest that state actors must be aware of long-term innovation cycles and capitalize on them with large investments at critical moments. 
optimal outcomes. Neo-schumpetarian economic theory had captured the attention of the Council and the Commission, and it has since become the mental model on which the Europe 2020 Strategy was constructed.

Correlating an ideational connection between the Lisbon Strategy and Europe 2020 does not prove that policy preferences were determined by an attention heuristic, but it does make Jacobs' mental model theory a likely theoretical framework to find out. Drilling down to the causal mechanisms is beyond the scope of this paper, and explaining exactly how the ideas of a particular epistemic community caused the policy preferences of powerful EU actors remains an empirical question for further research. However, a strong correlation between the policy outcomes of Europe 2020 and the policy ideas that led to the Lisbon Agenda can inform what methodological tools might have the most leverage. If Hall's descriptive theory was most useful, one would anticipate a change in policy goals to see social learning in action. This would be preceded by changes in policy settings and instruments in response to anomalies and policy failures in the Lisbon Agenda. Significant anomalies and failures did occur: the mid-term Kok report (2004) pointed out numerous policy failures, and the Aho report (2006) criticized innovation policy and R\&D. While settings and instruments were adjusted to refocus the Agenda on growth and employment, there was never any third-order change in policy goals-causal beliefs and attention to goals were reinforced by these reports, not undermined by them. Therefore, despite the widely perceived failure of the Lisbon Strategy, a Kuhnian paradigm shift did not occur for Europe 2020. For Blyth's theory to be useful for understanding Europe 2020, one would anticipate a critical juncture of Knightian uncertainty opening up actors' policy preferences to new economic ideas. The global recession and subsequent euro zone crisis would seem to be exactly this sort of critical juncture. However, despite such externally-induced shocks, the Council continues to promote free, fair and open trade, and focus on concluding freetrade agreements, either multilaterally through the World Trade Organization, or bilaterally, like the Canada-EU Comprehensive Economic and Trade Agreement (CETA). Rather than restructuring interests to reflect new economic ideas about market capitalism, perhaps looking for new ideas or returning to a more protectionist 'managed globalization' policy platform, the Council has emphasized a competitive external dimension to the single market (Council, 2011, pgs. 4-5). The crisis has reinforced the neo-schumpetarian mental model, albeit with even greater need for coordination of national and European policy to ensure fiscal discipline. Europe 2020 expresses an idea that more effective policy coordination will allow a quick exit strategy from the crisis so that member states can re-focus on the goals of innovation-driven economic growth. Fiscal consolidation is expected by 2013, and lessons learned about efficient and strategic budgeting are expected to capture some of the actors' attention well into the future, but the fundamental goals and priorities - and the neo-schumpetarian mental model - have not changed since Lisbon (Commission, 2010b, pg. 24).

\section{Conclusion}

The Europe 2020 Strategy suggests that ideas have causal salience. While policy outcomes are often determined by a number of conjunctural factors (i.e., ideas, interests and institutions), social scientists seldom acknowledge that policy-makers are also cognizant of interacting causes. I believe that savvy political elites exhibit what Pierre Bourdieu has called a 'feel for the game,' an awareness of how to achieve material interests within institutional opportunities and constraints. This structuration of interests — manifest in policy preferences - is the result of a 
constructed mental model of the world. These models, or ideas, are often quite resilient. They offer a heuristic of reality that focuses the attention on particular information or evidence, as well as certain possibilities in terms consequences and preferences. Using Jacobs's theory of mental models and attention heuristics, I have described how neo-schumpetarian ideas influential for the Lisbon Agenda have since become the policy outputs of the Europe 2020 Strategy. I paid closer attention to innovation and education polices because they are the vital inputs for the primary driver of endogenous economic growth - the 'smart growth' pillar. The next step would be to process-trace the causal mechanisms that connect economic ideas to the policy preferences of particular actors, such as the Commission DG for Research and Innovation, or the Commission DG for Education and Culture. Yet even at this stage, a connection between neo-schumpetarian ideas and Europe 2020 outcomes has practical and normative implications. The normative implications raise questions about the legitimacy of these ideas for the EU, asking: whose ideas matter? One way of answering this question amounts to a general critique of capitalism, yet there are also answers which draw attention to a European democratic deficit. ${ }^{16}$ The practical implications question the effectiveness of neo-schumpetarian ideas as a model for the European economy, asking how the plan can remain coherent. For example, the European Semester seems to privilege the SGP (fiscal constraint) over Europe 2020 (macro-economic growth). Even if the powerful actors, like the Commission, are able to reconcile these two ideas in a single mental model, it does not mean others will share that schema. As Commission President Barroso has already admitted, "we have to be quite honest with you, there are 27 member states and if they don't want to play ball nothing will happen” (Willis, 2010). To return to Bourdieu's 'feel for the game' metaphor, political elites in the Member States not only need to share the causal beliefs of Europe 2020, but they must also have the political will to achieve its goals.

\section{References}

Abdelal, Rawi, and Sophie Meunier. 2010. "Managed globalization: doctrine, practice and promise.” Journal of European Public Policy 17(3): 350-367.

Aghion, Philippe, and Peter Howitt. 1992. "A Model of Growth Through Creative Destruction.” Econometrica 60(2): 323-351.

Aho, Esko, and et. al. 2006. Creating an Innovative Europe. Luxembourg: Office for Official Publications of the European Communities

Beck, Ulrich. 2009. World at Risk. Cambridge and Malden, MA: Polity Press.

Bleich, Erik. 2002. "Integrating Ideas into Policy-Making Analysis: Frames and Race Policies in Britain and France.” Comparative Political Studies 35(9): 1054-1076.

Blyth, Mark. 2002. Great Transformations: Economic Ideas and Institutional Change in the 20th Century. New York: Cambridge University Press.

16. Typically, these critiques over-emphasize a deficit of representative democracy and underestimate the legitimacy of deliberative democracy. However, the danger to deliberative democracy in allowing a small group of unelected political actors to form policy based on the ideas of an epistemic community is that the deficit might be self-reinforcing if powerful actors do not work to prevent it. The governance process of Lisbon marginalized the European Parliament and the European Court of Justice, and concentrated power with the Commission or the Member State governments (either as sovereign states or sitting in the European Council). Furthermore, experiences with the OMC have shown that subordinate aims and indicators can have a considerable influence on discrete policy evaluations, focusing attention on financial inputs and leading to demands for recommodification (Hacker \& Van Treeck, 2010). 
Castells, Manuel, and Gustavo Cardoso. 2005. The Network Society: From Knowledge to Policy. eds. Manuel Castells and Gustavo Cardoso. Washington, D.C.: Johns Hopkins Center for Transatlantic Relations.

Eckstein, Harry. 1992. Regarding Politics: Essays on Political Theory, Stability, and Change. Berkeley and L.A.: University of California Press.

European Commission. 2005. Common Actions for Growth and Employment: The Community Lisbon Programme. Brussels, COM(2005) 330 final. 2006. Frequently Asked Questions : Why does the EU need a European Institute of Technology? Brussels, MEMO/06/88.

—. 2010a. “Europe 2020.” http://ec.europa.eu/europe2020/index_en.htm . . 2010b. “Europe 2020 - Public Consultation. Overview of responses.” Europe (March): $1-31$.

- 2010c. Europe 2020: A European strategy for smart, sustainable and inclusive growth. Brussels, COM(2010) 2020.

- 2010d. Europe 2020: Integrated guidelines for the economic and employment policies of the Member States. Brussels, COM(2010) 488 final.

- 2010e. Proposal for a Council Decision on guidelines for the employment policies of the Member States. Part II of the Europe 2020 integrated guidelines. Brussels, COM(2010) $193 / 3$.

European Council. 2000. Presidency Conclusions: Lisbon European Council. 23 and 24 March 2000. Lisbon. http://consilium.europa.eu/ueDocs/cms_Data/docs/pressData/en/ec/00100r1.en0.htm.

—. 2011. European Council Conclusions, March 2011. Brussels. http://www.europeancouncil.europa.eu/council-meetings/conclusions.

European Council of Ministers of Economics and Finance. 2010. Council Recommendations on broad guidelines for the economic policies of the Member States and of the Union. Brussels, (2010/410/EU).

European Economic and Social Committee. 2011. Europe 2020 Strategy: Civil Society Involvement in the National Reform Programmes. Brussels. http://www.eesc.europa.eu/?i=portal.en.news.16037.

Evans, P. 2008. “Is an Alternative Globalization Possible?” Politics \& Society 36(2): 271-305.

Freeman, Christopher, and Francisco Louca. 2001. As Time Goes By: From the Industrial Revolutions the Information Revolution. Oxford: Oxford University Press.

“From brawn to brain.” 2012. The Economist (10-16 March): 23.

Goldstein, Judith, and Robert Keohane. 1993. "Ideas and Foreign Policy: An Analytical Framework.” In Ideas and Foreign Policy: Beliefs, Institutions and Political Change, eds. Judith Goldstein and Robert Keohane. Ithaca, N.Y.: Cornell University Press, p. 330.

Haas, Peter. 1993. "Introduction: Epistemic Communities and International Policy.” International Organization 46: 1-35.

Hacker, Björn, and Till Van Treeck. 2010. "What influence for European governance? The Reformed Stability and Growth Pact, the Europe 2020 Strategy and the European Semester”, Friedrich-Ebert-Stiftung, International Policy Analysis, December 2010. http://library.fes.de/pdf-files/id/ipa/07724.pdf

Hall, Peter A. 1993. "Policy Paradigms, Social Learning, and the State: The Case of Economic Policymaking in Britain.” Comparative Politics 25(3): 275-296. 
Heclo, Hugh. 1974. Modern social politics in Britain and Sweden: From relief to income maintenance. New Haven, CT: Yale University Press.

Howlett, Michael, and M. Ramesh. 1995. Studying Public Policy: Policy Cycles and Policy Subsystems. Toronto: Oxford University Press.

Jakobi, Anja P. 2009. International Organizations and Lifelong Learning: From Global Agendas to Policy Diffusion. New York: Palgarve MacMillan.

Kingdon, John W. 1984. Agendas, Alternatives and Public Policies. Boston: AddisonWesley Educational Publishers.

Kok, Wim, et. al. 2004. Facing the Challenge: The Lisbon strategy for growth and employment. Report from the High Level Group chaired by Wim Kok, November 2004. Luxembourg: Office for Official Publications of the European Communities. http://ec.europa.eu/information_society/tl/essentials/reports/kok/index_en.htm.

Oberndörfer, Ulrich. 2011. "Lessons for Canadian climate policy? Insights from the EU ETS' first phase.” In Europe, Canada and the Comprehensive Economic and Trade Agreement, ed. Kurt Hübner. New York: Routledge, p. 245-258.

Palmer, Karen, Wallace E. Oates, and Paul R. Portney. 1995. “Tightening Environmental Standards : The Benefit-Cost or the No-Cost Paradigm ?" The Journal of Economic Perspectives 9(4): 119-132.

Platform of European Social NGOs. 2009. Social Platform. Brussels. http://www.euractiv.com/priorities/eu-new-2020-strategy-comes-fire/article-187582.

Polanyi, Karl. The Great Transformation: The political and economic origins of our time. Boston: Beacon Press.

Porter, Michael E., and Claas van der Linde. 1995. "Toward a New Conception of the Environment-Competitiveness Relationship.” The Journal of Economic Perspectives 9(4): 97-118.

Rodrigues, Maria Joao, et. al. 2009. Europe, Globalization and the Lisbon Agenda. ed. Maria Joao Rodrigues. Northampton, MA: Edward Elgar Publishing Inc.

Scharpf, Fritz W. 1999. Governing in Europe: effective and democratic? Oxford: Oxford University Press.

Schumpeter, Joseph. [1942] 1994. Capitalism, Socialism and Democracy. London: Routledge. The Treaty on the Functioning of the European Union. 2008. Europe 1-153.

Willis, Andrew. 2010. “Lukewarm Reaction to Europe 2020 Plan.” Bloomberg Businessweek. http://www.businessweek.com/globalbiz/content/mar2010/gb2010035_390728.htm.

Zuleeg, Fabian, and Maria Joao Rodrigues. 2011. "Implementation of Europe 2020: Time to Act.” Brussels: European Policy Centre. http://www.epc.eu/documents/uploads/pub_1790_tgae2011zuleeg.pdf 
Correct citation: King, Conrad. 2012. "Mental Modes and the Europe 2020 Strategy: Neoschumpetarian Ideas in Innovation and Education". Review of European and Russian Affairs 7 (2): 1-14.

Published by the Centre for European Studies at Carleton University, Ottawa, Canada. Available online at: www.carleton.ca/rera/

RERA is an electronic academic peer-reviewed journal that publishes graduate, post-graduate, and young scholarly works. Topics relate to the European Union, its Member States, the former Soviet Union, and Central and Eastern Europe. The journal is a joint project supported by the Canada-Europe Transatlantic Dialogue-a cross-Canada research network supported by the Social Sciences and Humanities Research Council of Canada (SSHRC)—along with the Institute of European, Russian and Eurasian Studies (Carleton University) and its associated research unit, the Centre for European Studies.

RERA aims to provide an accessible forum for research, to promote high standards of research and scholarship, and to foster communication among young scholars.

\section{Contact:}

Carleton University

The Centre for European Studies

1103 Dunton Tower

1125 Colonel By Drive

Ottawa, ON

K1S 5B6

Canada

Tel: +01 613 520-2600 ext. 1179; E-mail: rera-journal@carleton.ca

\section{Creative Commons License}

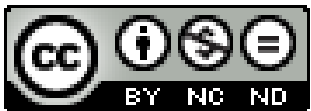

http://creativecommons.org/licenses/by-nc-nd/3.0/

This Working Paper is licensed under a Creative Commons Attribution-Non-CommercialNo Derivs 3.0 Unported License (CC BY-NC-ND 3.0).

Articles appearing in this publication may be freely quoted and reproduced provided the source is acknowledged. No use of this publication may be made for resale or other commercial purposes.

ISSN: 1718-4835

(C) 2012 The Author(s) 